\title{
The Research of Service Quality Evaluation in Logistic and Express Industry
}

\author{
Xiao Zhen \\ Continuous Education College \\ Shengyang Aerospace University \\ Shengyang China \\ Xiaozhen@sau.edu.cn
}

\begin{abstract}
With the development of modern express industry, it has become an industry with huge profit and potential. The domestic express industry has been the rapid development at the rate of $\mathbf{3 0}$ percent annually, so far, which has formed the market with hundreds of billion a year .Once upon a time, China Postal was the only express company in Chinese market. But now, more and more express companies have showed up in China, including state-owned, foreign , private and other forms of ownership, which has already formed the market with a variety of modes of transport competing with each other. As the first standard of express implemented, the competition of express market has become intensified, that means the system of service quality evaluation is needed.On the basis of explaining the concept of express delivery and quality of service, the papers analyzes the situation of logistics and express industry, and then establishes the system of the quality evaluation.The paper elaborated the problem of logistics and express industry and then put forward a solution by designing questionnaire and doing research. Nowadays, logistics has related to all aspects of our daily life, so the better it developed,the better service we will get.
\end{abstract}

Keywords: Express industry; service quality; evaluation system

\section{INTRODUCTION}

At present, there are more than ten thousand enterprises engaged in express delivery business in our country with hundreds of thousands of practitioners and business scale of tens of billions of RMB, and their volume of business maintains the growth rate more than $30 \%$. China has become the fastest growing market in global express market.

Emergence of express industry is better satisfied with the needs of the society to transport goods fast and safely, and has played a positive role in the development of economy and society and meets people's life demand. With the increasing demand of express service, the quality of express service has become the focus concerned by the masses of customers. However, due to various factors, the service quality of China's express delivery enterprises is not ideal on the whole with some obvious problems and cause complaints from many customers, which greatly hindered its better development.

Studying on the express service quality evaluation has the following three points:

Understanding needs of customer and their satisfaction to express service;

Identifying the key factors affecting customer satisfaction and calculating customer satisfaction value to make regular investigation on customer satisfaction for the enterprises and compare the change of customer satisfaction;

Finding direction to improve customer satisfaction, so that enterprises adjust business strategy.

Given the role express played in the economy, the society and life becomes more and more important, but most of the express enterprises in our country exists many problems. Therefore, the author writes this article, and hopes to make some contribution to the development of China express enterprises.

\section{ANALYSIS OF THE DEVELOPMENT STATUS OF LOGISTICS INDUSTRY}

\section{A. The Concept of Logistics Express}

Logistics is the flow process that the goods is sent from the supply to the accepted. According to the actual need, it combines the basic functions of transportation, storage, loading and unloading, handling, packaging, distribution processing, distribution, information processing and other basic functions organically. According to the definition of logistics, it can be seen clearly that the express industry is not only part of logistics industry but is one of the high added value of logistics industry.

The core and soul of express is "fast", and the subject is "delivery". Delivery is actually a kind of behavior of transmission, transport and transfer; "fast" is the result of this behavior. Express delivery is the expressing process with the fastest speed.

\section{B. The Development and Present Situation of Express Delivery}

1) The Present Situation of Express Delivery in Our Country

The express industry in China has formed a large-scale industry after 30 years of development. In 2010, the registration of the express delivery enterprises has reached more than 5,000 with 240,000 practitioners in the whole industry. In 2010, the total volume of express business above national scale is $1,860,000,000$ with a year-on-year growth of $22.8 \%$; the total of business revenue is $47,900,000,000$ yuan with a year-on-year growth of $17.3 \%$. The city, remote, international and Hong Kong and Macao express business income accounted for $7.3 \%, 55.7 \%$ and $31.7 \%$ of all express income separately; the volume of business accounted for $23.5 \%, 70.4 \%$ and $6.1 \%$ of all volume of the express business.

In December, the business income of whole industry is $14,500,000,000$ yuan with a year-on-year growth of $17.9 \%$; 
business volume totaled 15,860,000,000 yuan with a yearon-year growth of $26.4 \%$.

In 2011, the postal mail service totaled 7,380,000,000 with a year-on-year down of $0.3 \%$; Parcel service totaled $68,806,000$, an increase of $4.3 \%$ compared to the same period; the newspaper business totaled 18,170,000,000, an increase of $5.8 \%$ compared to the same period; the magazine business totaled 1,080,000,000, an increase of $2.7 \%$ compared to the same period; the remittances totaled $260,000,000$, a drop of $5.6 \%$ compared to the same period.

In 2011, the business volume of express service enterprises above national scale totaled 3,670,000,000, an increase of 57\%; business revenue totaled 75,800,000,000 yuan, a year-on-year growth of $31.9 \%$. Among them, the city business revenue totaled 6,590,000,000 yuan, a yearon-year increase of $58.8 \%$; remote business revenue totaled 44,590,000,000 yuan, a year-on-year growth of $41.8 \%$; international and Hong Kong and Macao business revenue totaled $18,470,000,000$ yuan with a year-on-year growth of $3.3 \%$.

In December, the express business completed $430,000,000$, an increase of $62.6 \%$ compared to the same period; the business income totaled 8,500,000,000 yuan with a year-on-year growth of $44.9 \%$. As is shown in Fig 2.1, Fig 2.2 and Fig 2.3.

Note: 1. Using 2010 constant price to calculate total business volume of postal industry for 2011 years.

2) The postal savings bank direct revenue is not included in the business income of postal I;ndustry.

\section{Problems existing in China's express industry}

Although Chinese express industry has gotten great progress after 30 years of development, the development prospects of China's express industry is very broad. Foreign enterprises brought advanced technology and ideas, activated the consciousness of market competition, and promoted the development and growth of express market after they entered into China. China's express delivery service quality and service consciousness has been greatly improved, but compared with the rapid development of express industry and people's upgrade need of service quality, the express industry quality obviously has more room to improve, especially the speed of development of private express makes a spurt of progress and obtain more attention from people. However the problems existing in the service process of express industry can not be ignored. With the enhancement of people's sense of time, express has become an inevitable choice for many people to deal with the daily affairs of the industry, but the problems of fast delivery also affect the trust and location of this industry.

From the analysis of the service process, the problems in China's express delivery companies are embodied in this group of private express delivery companies.

1) Low quality of employees.

Most employees engaged in express service industry are laid-off workers and urban youth waiting for employment, whose cultural level is generally low. The cultural level and the management level of enterprise management personnel are not high, and seldom of them have junior college degree or above. And because of the hard work and low pay of express industry, it is difficult to attract high-quality and stable staff.

\section{2) Poor service level.}

Due to low cultural quality and lack of system and formal training the courier service industry workers commonly suffer the problems such as unfamiliar with business, lack of technology, service untimely and unfulfilled and so on.

From the analysis of the service quality, China's express service problems mainly exist in the process of express delivery.

Concerning from current situation of the development of Chinese express industry, since China access to the WTO, foreign express delivery companies are piling into the Chinese market, and these advanced enterprises have strong competitive advantages both in the business philosophy, technical facilities or management methods. Although China's express delivery enterprises, especially private express delivery enterprises show very strong vitality, which annual business volume has increasing speed from $60 \%$ to $120 \%$, they also exposed a lot of problems. Express service is being questioned by the majority of customers, and the complaints about relevant express increase progressively.

\section{The Evaluation of Logistics SERVICE Quality}

\section{A. The Overview of Service Quality}

\section{1) The Connotation of Service Quality}

Service Quality generally has the characteristics of function, economy, safety, timeliness, comfort and civilization:

\section{2) Characteristics of Service Quality}

Service is different from tangible product. Tangible products are solid material with real image and characteristics. While service is to meet a series of behavior, actions and activities specifically required by customers, so it has characteristics of intangibility, difference, inseparability and non storability.

\section{3) The Elements of Service Quality}

When receiving service, our clients not only pay attention to the service result, but also pay more attention to the service process. Therefore, the quality of service is composed of two parts: technical quality and functional quality:

\section{a) Technical Quality}

Technical quality is the output quality of service process also called the level of real output customer obtained from the service process. It reflects the quality situation that enterprises provide customers with the service result, so it is also called the result quality.

\section{b) Functional Quality}

Functional quality is the sensory interest and enjoyment of customers received related elements of the service in the promotion of service such as service environment, service equipment, and service personnel and so on. It reflects how customers obtain the related services, so it is also called the process quality.

\section{B. The Establishment of Logistics Enterprise Service Quality Evaluation System}

Design principles of express service quality evaluation system

In order to reflect the express service quality scientifically and objectively, we should consider 
establishing service quality evaluation method which adapts with it, and determine the corresponding quality evaluation index system. In actual operation, we should obey the following principles:

\section{1) Scientific normative principle}

To evaluate the express service quality, first of all, we should keep the spirit of scientific attitude and guarantee the existence of the causal relation between the evaluation characteristics and collected material, or the inner direct link.

\section{2) Systemized optimization principle}

The evaluation index system of express company service quality shall be able to reflect all aspects of the delivery service quality, so it must use some index contacting and restraining with each other. There are horizontal linkages among some indexes, which reflect interacted relationship from different aspects; and there are longitudinal linkages among some indexes, which reflect the relation of inclusion between the different levels.

\section{3) Simple and clear principle}

The evaluation index system of express company service quality shall be moderate, which calculation and evaluation methods are simple. In the basic guarantee of objective and comprehensive evaluation results, the index system should be simplified as much as possible, and reduce or remove some index that has little effect on the results of evaluation.

\section{4) The comprehensive and practical principle}

The evaluation index system of express company service quality shall be the completely, multi angle and multi-level reflection of the service result of express enterprises. The related index also shall have a clear meaning, and be feasible in actual operation. The evaluation results must be consistent with the actual service quality level of express enterprises.

5) The maneuverability principle

Although many indexes are not enough to reflect the characteristics of certain aspects of the express service, some idealized index can accurately reflect the service quality of express enterprises by theory. However, the basic information that depended by these idealized index may not collected in the present condition.

\section{CONCLUSION}

On the approach of data collection, this paper uses the customer survey to obtain the initial data, which not only ensures the quickness and timeliness of the customer evaluation information, but the acquired data can represent the most direct customers opinion to make the research results more credible.

In addition, multi period evaluation results should be compared to find some changes of some aspects of service quality, so that we can grasp the trend of the level of service quality, find problems timely and provide information support for the improvement of existing services and the development of new services.

The purpose of this study is to be suitable for the service quality evaluation system of China's express delivery industry, provide a reliable service quality evaluation tool for the express delivery company, and hope to attract more people to pay attention to the service quality and obtain more scholars to conduct in-depth research on the evaluation of service quality. With the continuously upgrade status of service industry in the economic structure and the rapid development of express industry, the realistic significance to research the express industry service quality evaluation will be more significant. As science and technology developed, the evaluation of service quality should also be improved continuously with the development of era.

\section{REFERENCE}

[1] Chen Chunli. Application Research on Logistics Service Quality Management of Express Enterprises [D]: Jiangxi: Jiangxi University of Science and Technology, 2010

[2] Sa Rula. The Research on the Customer Satisfaction to Private Express Service[D]. Beijing: Beijing Jiaotong University, 2010

[3] Qiu Guansheng. The Research on the analysis and improvement of the express delivery service quality[D]. Xi'an: Chang'an University, 2008

[4] Li Shaorong. The Study on the Logistics Capability of Express Enterprise Based on the Customer Satisfaction[D]., Beijing: Beijing Jiaotong University, 2010

[5] Oxford Economic Forecasting The Impact of The Express Delivery Industry On The Global Economy , March 2005.

[6] He Guojie and Han Guoli. The Competition and Cooperation of Express Delivery Industry[J]. Science and Technology Information, 2007 (30), 197-198

[7] Kang Jian, Zheng Zhaohong and Tang Wan Jin. The Study on Evaluation System and Standard System of Service Quality[J]. World Standardization and Quality Management, 2008 (L): 49 - 51

[8] Hua Aimei. The Study of the Service Quality Evaluation of Logistics Enterprises[D]. Nanjing: Nanjing University of Science and Technology, 2010.

\begin{tabular}{l|l}
\hline characteristics & description \\
\hline $\begin{array}{l}\text { function } \\
\text { economy }\end{array}$ & $\begin{array}{c}\text { The function and efficiency that service plays to meet the degree of needs } \\
\text { reasonable or not }\end{array}$ \\
\hline safety & Service in time to meet customer needs, that is to be timely, on time and \\
& save time \\
\hline
\end{tabular}




\begin{tabular}{l|l}
\hline timeliness & $\begin{array}{r}\text { Security level of safety on customer's health, spirit, life, property, goods } \\
\text { in the process of serving }\end{array}$ \\
\hline comfort & $\begin{array}{r}\text { The comfortable degree of the service process, including comfortable, } \\
\text { convenient and applicable facilities, and clean, beautiful and orderly } \\
\text { environment, etc.. }\end{array}$ \\
\hline civilization & $\begin{array}{r}\text { The degree of civilization of the service process, including a cordial and } \\
\text { friendly atmosphere, harmonious interpersonal relationships, etc.. (such } \\
\text { as customer's psychological needs) }\end{array}$ \\
\hline
\end{tabular}

Figure .1 characteristics of service quality 